\title{
POPULAR HISTORY, POST-WAR LIBERALISM, AND THE ROLE OF THE PUBLIC INTELLEGTUAL IN RICHARD HOFSTADTER'S THE AMERICAN POLITICAL TRADITION (1948)*
}

\author{
N I CK W ITHAM \\ University College London
}

\begin{abstract}
A B S T R ACT. This article examines the status of Richard Hofstadter's classic work The American political tradition (I948) as a 'popular history'. It uses documents drawn from Hofstadter's personal papers, those of his publisher Alfred A. Knopf, Inc., as well as several of his contemporaries, to pursue a detailed reconstruction of the manner in which the book was written, edited, and reviewed, and to demonstrate how it circulated within, and was defined by, the literary culture of the I940s and 1950s. The article explores Hofstadter's early career conception of himself as a scholar writing for audiences outside of the academy, reframes the significance of so-called 'middlebrow' literature, and, in doing so, offers a fresh appraisal of the links between popular historical writing, liberal politics, and the role of public intellectuals in the post-war United States.
\end{abstract}

Institute of the Americas, University College London, ${ }_{5}$ I Gordon Square, London, WCIH OPN n.witham@ ucl.ac.uk

* I would like to thank Jonathan Bell, Owen Dudley Edwards, Dan Geary, Simon Hall, Iwan Morgan, Michael O'Brien, Lydia Plath, Leo Ribuffo, Dan Scroop, Robin Vandome, and several anonymous reviewers for the incisive critical readings and thoughtful comments they provided as I wrote and revised this article. I am grateful to Andrew Preston for steering me through the editorial process, and to Eric Foner for generously permitting me to quote from an oral history interview about Richard Hofstadter that he recorded in 1973. I would like to acknowledge funding I received to undertake research on the article from the US-UK Fulbright Commission, the Institute of the Americas at University College London, and the Institute for Advanced Study in the Humanities at the University of Edinburgh. Final revisions were undertaken while I was an Arts and Humanities Research Council International Placement Scheme fellow at the Kluge Center, Library of Congress, Washington, DC. Lastly, I would like to show my appreciation to the staff of the Rare Book and Manuscript Library at Columbia University in the City of New York, the Berg Collection and the Manuscripts and Archives Division at the New York Public Library, and the Harry Ransom Center at the University of Texas at Austin for all of their support in locating the archival material upon which the article is based. 
The experience of the Second World War turned the meaning and relevance of national history into an urgent topic of discussion in the post-war United States. Concepts such as the 'American mind' and 'the national character' peppered popular discourse, giving rise to potent and competing understandings of how US history should be characterized. American historians played a key role in these debates, searching anxiously for answers to a question that had haunted the profession since it was voiced by the president of the American Historical Association (AHA) in 1936: what part would the historian play in 'a changing world'?' For a generation of post-war scholars, the answer lay in attempts to engage public audiences through popular historical writing aimed at what were commonly referred to as 'general readers'. These attempts were facilitated by the expansion of US higher education and the concurrent 'paper backing' of the publishing industry, phenomena that provided an audience for historians and other scholars amongst so-called 'middlebrow' readers keen to engage with complex ideas about American life. Ultimately, these factors led trade publishers such as Alfred A. Knopf, Inc., and Random House to commission an increasingly large volume of writing by professional historians, thereby providing a host of scholars with the opportunity to function as public intellectuals.

It was in this context that the thirty-two-year-old Columbia University historian Richard Hofstadter published his second book, The American political tradition and the men who made it (1948). On the surface, the work was an orthodox one, consisting as it did of twelve biographical chapters on specific individuals or groups of individuals already prominent within US historiography, from the Founding Fathers, Andrew Jackson, and Abraham Lincoln, to William Jennings Bryan, Woodrow Wilson, and Franklin D. Roosevelt. However, Hofstadter's arguments were provocative, the book sold enormously well, and has since become a classic of US historical writing. Congratulating Hofstadter on the impending publication of the book in April 1948, his doctoral adviser, the University of Wisconsin-Madison scholar Merle Curti, told the young historian that he had done 'a skilful job-and a very hard one, with much insight...I predict it will be accepted as popular history in the best sense.' ${ }^{2}$ Curti's description suggested that Hofstadter had produced a book that would appeal to audiences outside of the American historical profession. But in describing the work as popular history at its 'best', Curti also made the point that Hofstadter had not pandered to patriotic sentiment about the American past. Instead, he had challenged his target audience by introducing an unusual degree of complexity into his narrative. In the weeks and months that followed the publication of The American political tradition, Curti's opinion

${ }^{1}$ C. H. McIlwain, 'The historian's part in a changing world', American Historical Review, 42 (1937), pp. 207-24. The journal printed the president's address as it was delivered the year before at the annual meeting of the AHA.

${ }^{2}$ Curti to Hofstadter, ${ }_{5}$ Apr. 1948, Alfred A. Knopf papers, Harry Ransom Center for the Humanities, University of Texas at Austin (AAKP), box 3o, folder 12. 
was confirmed, as the phrase 'popular history' was used repeatedly by both scholarly and popular reviewers, who celebrated the book's entertaining prose style and the relevance of its historical insight to mid-century politics and culture, whilst also commenting on the book's literary and intellectual merits.

The most prominent debate that has developed in the scholarly literature on Richard Hofstadter relates to his interaction with so-called 'consensus' historiography. ${ }^{3}$ In the introduction to The American political tradition, Hofstadter drew the book's chapters together by arguing that they demonstrated the existence of a 'common climate of...opinion' throughout American history, based on a set of shared values that 'accepted the economic virtues of capitalist culture as necessary qualities of man'. In particular, these values consisted of property rights, economic individualism, and the spirit of competition, all of which had been prioritized by the politicians, businessmen, and intellectuals Hofstadter analysed, regardless of their party affiliations. 4 In the years after the publication of the book, this argument for the centrality of bourgeois values to American historical development came to be viewed as one of the founding statements of the consensus school, with its proponents generally painted as opponents of the 'progressive' analysis of Frederick Jackson Turner, Charles A. Beard, and Vernon L. Parrington, who saw conflict between rival economic groups as the driving force behind American historical development. 5 Instead of such class conflict, consensus historians emphasized the remarkable unity of, in political scientist Louis Hartz's phrase, the American 'liberal tradition', which drew the nation together around a common set of political and economic beliefs. ${ }^{6}$

3 The two book-length treatments of Hofstadter's biography are Susan Stout Baker, Radical beginnings: Richard Hofstadter and the I93os (Westport, CT, 1985), and David S. Brown, Richard Hofstadter: an intellectual biography (Chicago, IL, 2006). See also Arthur Schlesinger, Jr, 'Richard Hofstadter', in Marcus Cunliffe and Robin D. Winks, eds., Pastmasters: some essays on American historians (Westport, CT, 1969); Daniel Walker Howe and Peter Elliott Finn, 'Richard Hofstadter: the ironies of an American historian', Pacific Historical Review, 43 (1974), pp. 123; Daniel Joseph Singal, 'Beyond consensus: Richard Hofstadter and American historiography', American Historical Review, 89 (1984), pp. 976-1004; Jack Pole, 'Richard Hofstadter', in Robert Allen Rutland, ed., Clio's favorites: leading historians of the United States, I945-200o (Columbia, MO, 2000); James Livingston, 'On Richard Hofstadter and the politics of "consensus history”, boundary 2, 34 (2007), pp. 33-46.

4 Richard Hofstadter, The American political tradition and the men who made it (New York, NY, 1948), pp. xxxvi-xxxvii.

5 See Charles Crowe, 'The emergence of progressive history', Journal of the History of Ideas, 27 (1966), pp. 109-24; Richard Hofstadter, The progressive historians: Turner, Beard, Parrington (New York, NY, 1968); Peter Novick, That noble dream: the 'objectivity question' and the American historical profession (Cambridge, 1988), pp. 86-110; Ernst A. Breisach, American progressive history: an experiment in modernization (Chicago, IL, 1993); David S. Brown, Beyond the frontier: the Midwestern voice in American historical writing (Chicago, IL, 2009), pp. 3-74.

${ }^{6}$ Louis Hartz, The liberal tradition in America (New York, NY, 1955). For important discussions of consensus thinking about American history and politics, see Gene Wise, American historical explanations: a strategy for grounded inquiry (Homewood, IL, 1973); Bernard Sternsher, 
Writing in 1962 in the American Historical Review, John Higham cited Hofstadter when he voiced a commonly held objection to the work of consensus historians: in searching for 'uniformity', 'stability', and an all-encompassing 'national character' in American history, he argued, they evidenced an inherently 'conservative trend of historical interpretation'. Wedded to the goals of Cold War ideology, this trend sought to use history to demonstrate the superiority of the American system of government to that of the Soviet Union.7 However, as Leo Ribuffo has suggested, Higham's denouncement of consensus history's approach to the US past 'obscures as much as it clarifies'. ${ }^{8}$ Likewise, a predominant focus on Hofstadter's connection with the consensus school has meant that the context provided by a different set of debates - i.e. those about the explicitly public function of US historical writing - has been largely ignored. This means that the entwined literary and political problematics addressed by The American political tradition have gone overlooked: first, Hofstadter's attempt to author popular history, reach out to audiences beyond the academy, and therefore complicate what has come to be understood as the 'middlebrow' of US culture; second, his desire to articulate opposition to the predominant climate of nostalgia regarding the national past, and to replace this with a more complex rendering of its key political figures that would speak to the specific debates taking place between American liberals in the late 1940s. Hofstadter was a consensus historian, then, but a close reading of The American political tradition demonstrates that he was no cheerleader for the political culture of individualism and laissez-faire that he described. As he reflected in 1968, to suggest that consensus history was intrinsically celebratory is to 'assume that the consensus idea is... a prescriptive one which commits us to this or that particular arrangement'.9 Instead, in the work of consensus scholars such as Hofstadter, Hartz, and the literary critic Leo Marx, there remained 'radical echoes' of political sensibilities forged in the 1930s, which shaped ideas and arguments about consensus 'not to champion them, but to welcome their demise'. ${ }^{10}$

These arguments were shaped by the particular political climate that existed in late 1940s America. According to intellectual historian Richard Pells, the

\footnotetext{
Consensus, conflict, and American historians (Bloomington, IN, 1975); Donald W. White, 'History and American internationalism: the formulation from the past after World War II', Pacific Historical Review, $5^{8}$ (1989), pp. 145-72; and Wendy L. Wall, Inventing the 'American way': the politics of consensus from the new deal to the civil rights movement (Oxford, 2008); Mark Hulliung, ed., The American liberal tradition reconsidered: the contested legacy of Louis Hartz (Lawrence, KS, $2010)$.

7 John Higham, 'Beyond consensus: the historian as moral critic', American Historical Review, 67 (1962), pp. 6o9-25, at p. 613 .

8 Leo Ribuffo, 'What is still living in "consensus" history and pluralist social theory', American Studies International, $3^{8}$ (2000), pp. $42-60$, at p. 43 .

9 Hofstadter, The progressive historians, p. $45^{1}$.

${ }^{10}$ Howard Brick, 'The disenchantment of America: radical echoes in 195 os political criticism', in Kathleen G. Donohue, ed., Liberty and justice for all? Rethinking politics in Cold War America (Amherst, MA, 2012 ), pp. 157-84, at p. 160.
} 
central tenets within mainstream liberal thinking in the immediate post-war period were as follows: (1) the desire for a 'strong, charismatic' president in the mould of Franklin D. Roosevelt; (2) a belief that Keynesian economic policies were the only way to avoid depression and inflation; and, (3) a conviction that US co-operation with the USSR and active participation in the United Nations were essential to post-war global stability. On each of these scores, Roosevelt's successor in the White House, Harry S. Truman, was deemed a 'crushing disappointment' by the liberal intelligentsia. ${ }^{11}$ These political assumptions allowed for the existence of a 'powerful forum for social democratic ideas' in late 1940 os US political culture, one that only disappeared after approximately $195^{2}$, as the anti-statism provoked by the rapid escalation of Cold War ideology took hold (as represented by McCarthyism, but also a range of more localized political phenomena). ${ }^{12}$ Many liberal intellectuals therefore welcomed the establishment in 1948 of the Progressive Party by former Vice President Henry A. Wallace, who advocated what amounted to a continuation of the 'popular front' liberalism of the 1930s, and sought to draw together a coalition of left-wing groups around a platform of 'democratic revolution' in opposition to the anti-communism of the Truman administration. ${ }^{13}$

Hofstadter was a functioning constituent of this intellectual and political situation, and The American political tradition intervened directly in its key debates, in particular those relating to the strength of presidential leadership and the significance of Keynesian political economy. Indeed, the historian gestured towards this important context when he noted soon before his death that although the book 'appeared on the eve of the $195^{\circ}$, it was to a very large extent an intellectual product of the experience of the 193 os' $^{14}$ In other words, rather than being shaped by Cold War anti-communism, its attempt to use national history to engage with questions of political economy and the role of the federal government was shaped by the liberalism of the Depression era, which retained vital currency in the post-war public sphere.

A reconsideration of The American political tradition as a work of popular history therefore allows for several new ways of understanding the relationship between the post-war publishing industry and public ideas about American history and politics. First, the book provides an opportunity to understand the development of Hofstadter's conception of himself as a public intellectual,

11 Richard H. Pells, The liberal mind in a conservative age: American intellectuals in the I94os and I95os (Middletown, CT, 1989), pp. 54-8.

${ }^{12}$ Jonathan Bell, The liberal state on trial: the Cold War and American politics in the Truman years (New York, NY, 2004), pp. xiii-xvi.

13 Thomas W. Devine, Henry Wallace's 1948 presidential campaign and the future of postwar liberalism (Chapel Hill, NC, 2013), p. x. On the Wallace campaign and its significance for postwar liberalism, see also Alonzo L. Hamby, Beyond the new deal: Harry S. Truman and American liberalism (New York, NY, 1973); Allen Yarnell, Democrats and progressives: the 1948 presidential election as a test of postwar liberalism (Berkeley, CA, 1974); Jennifer Delton, 'Rethinking post-World War II anticommunism', Journal of the Historical Society, 10 (2010), pp. 1-41.

14 Hofstadter, The American political tradition, p. xxv. 
and to ground this understanding in a detailed analysis of his interaction with his publishers. Second, the book offers a new perspective on the circulation and significance of so-called 'middlebrow' American culture by demonstrating how those like Hofstadter who operated within its remit went beyond simplistic, nationalistic understandings of American society. Third, it allows for a fresh appraisal of the links between politics and historiography in the late 1940s, by offering a window into the way Hofstadter used his analysis of a broad sweep of US history to intervene in the political debates of the period. To achieve these goals, it is necessary to reconstruct the contexts in which the book was written, edited, publicized, and reviewed. In doing so, this article develops an approach to the study of historiography that treats popular history's conditions of authorship and publication as fundamentally entwined with the development and reception of popular political ideas about the past.

\section{I}

If insufficient scrutiny has been given to the relationship between Hofstadter's literary practice and his political ideas, a similar conceptual and methodological gap exists in the extant scholarship on twentieth-century US historical writing more generally. For example, several important books have charted the development of the discipline under a series of thematic rubrics, such as the 'objectivity question', the 'frontier', 'history's memory', and the 'Midwestern voice'. ${ }^{15}$ Other historians have written biographical studies of key figures in order to draw conclusions about the state of the field at a given moment. ${ }^{16}$ These approaches have provided numerous insights into the development of American historical practice since approximately 1884 , the year the AHA was founded, and the point from which most scholars date the origins of a professionalized, disciplinary ethos in the United States. However, they have tended not to pay close attention to the manner in which literary and political culture has shaped works of popular history aimed at audiences outside of the academy. ${ }^{17}$

Before examining the publication history of The American political tradition, then, some definitional clarity about the scope of 'popular history' is necessary. Whilst any rigid distinction between popular and scholarly formats is problematic, the term is functional, not least because it was used so often by mid-century

\footnotetext{
15 Novick, That noble dream; Kerwin Lee Klein, Frontiers of historical imagination: narrating the European conquest of native America, I890-I99o (Berkeley, CA, 1997); Ellen Fitzpatrick, History's memory: writing America's past, I880-1980 (Cambridge, MA, 2002); Brown, Beyond the frontier.

${ }^{16}$ Three examples amongst many are Neil Jumonville, Henry Steele Commager: mid-century liberalism and the history of the present (Chapel Hill, NC, 1999); Paul Buhle and Edward RiceMaximin, William Appleman Williams: the tragedy of empire (New York, NY, 1995); Eric Miller, Hope in a scattering time: a life of Christopher Lasch (Grand Rapids, MI, 2010).

${ }_{17}$ The work of Ian Tyrrell is an important exception here. See Ian Tyrrell, Historians in public: the practice of American history, I890-I970 (Chicago, IL, 2005). See also Erik Christiansen, Channeling the past: politicizing history in postwar America (Madison, WI, 2013 ).
} 
discussants of the book. The common denominator was the perception that a book defined as 'popular history' was primarily aimed at an audience outside of the academy. As has already been noted, The American political tradition was written for what Hofstadter and his editors perceived to be a 'general' readership. It was published by Knopf, a trade press, rather than an academic house such as the University of Pennsylvania Press, which had commissioned Hofstadter's first book, Social Darwinism in American thought (1944). As it was marketed during the late 1940 and throughout the 195 os, The American political tradition was aimed at general readers, college and high school students, as well as at historians and other scholars.

With the advent of Knopf's non-fiction paperback imprint, Vintage Books, the book began to circulate within the middlebrow literary networks disparaged at the time by New York Intellectuals such as Clement Greenberg and Dwight MacDonald, who preferred a version of avant-garde cultural development focused on 'little magazines' such as Partisan Review. ${ }^{18}$ However, as Joan Shelley Rubin has demonstrated, these networks were crucial to mid-century intellectual life. The emergence of middlebrow culture 'created an unprecedented range of activities aimed at making literature and other forms of "high culture" available to a wide reading public'. This, in turn, meant that publishers prioritized authors who could 'outline and simplify specialized learning'. ${ }^{19}$ Tim Lacy has described this process as the 'democratization of culture', whereby publishers sought to make so-called 'great books' available to wide audiences in order to function as 'an antidote...to that bland, conformist mass culture feared by midcentury critics'. ${ }^{20}$ This was a process that structured the meaning of The American political tradition within mid-century literary discourse: it made a contribution to debates about American history, politics, and society, and was consequently reviewed and discussed not only in scholarly journals, but also in major periodicals and daily newspapers at both the national and local levels. Whilst Hofstadter might be termed a fringe New York Intellectual, then, the way he capitalized on middlebrow distribution networks to expand his readership demonstrates the existence of a concrete alternative to the elitist conceptualization of the public intellectual usually associated with that group.

18 See Clement Greenberg, 'Avant garde and kitsch', Partisan Review, 6 (1939), pp. 34-49; Dwight MacDonald, 'Masscult and midcult I', Partisan Review, 27 (1960), pp. 203-33, and 'Masscult and midcult II', Partisan Review, 27 (1960), pp. 589-631. For discussions of the New York Intellectuals and their view(s) of American culture, see Terry A. Cooney, The rise of the New York Intellectuals: Partisan Review and its circle (Madison, WI, 1986); Alan M. Wald, The New York Intellectuals: the rise and decline of the anti-Stalinist left from the I93os to the I980s (Chapel Hill, NC, 1987); Neil Jumonville, Critical crossings: the New York Intellectuals in postwar America (Berkeley, CA, 1991); Hugh Wilford, The New York Intellectuals: from vanguard to institution (Manchester, 1995).

19 See Joan Shelley Rubin, The making of middlebrow culture (Chapel Hill, NC, 1992), pp. xi-xii.

${ }^{20}$ Tim Lacy, The dream of a democratic culture: Mortimer J. Adler and the great books idea (New York, NY, 2013), pp. 11-13. 
All of this meant that The American political tradition allowed Hofstadter the opportunity to model himself after the 'socially responsible intellectuals' of the Progressive era whom he had identified in Social Darwinism, most notably the pragmatist philosopher John Dewey. ${ }^{21}$ In doing so, he demonstrated the literary and political (rather than purely scholarly) ambitions of making US history relevant to post-war society and, more specifically, what he saw as the pitfalls of modern American liberalism. In focusing on The American political tradition, it is important not to lose sight of the argument Hofstadter made in the final paragraph of the book's introduction:

I have no desire to add to a literature of hero worship and national self-congratulation, which is already large. It seems to me less important to estimate how great our public men have been than to analyze their historical roles. A democratic society, in any case, can more safely be overcritical than overindulgent in its attitude toward public leadership. ${ }^{22}$

In making this point, Hofstadter demonstrated his desire for a popular audience, but also for the opportunity to articulate an inherently complex, anti-nostalgic analysis of US history that would serve a political as well as an intellectual purpose.

This important notion of historical complexity took on several interconnected valences. It stood for integrating a liberal - and, where appropriate, Marxist - political viewpoint into its retelling of the nation past. It also involved synthesizing the latest academic scholarship into readable prose. Finally, it meant introducing irony and tragedy as key themes of the book's narrative, in order to stress the persistent gap between the rhetoric of liberty and justice advanced by key historical actors and the turbulent realities of American inequality. Hofstadter reinforced this perspective towards the end of his career, when he suggested that good historical writing necessitated an awareness of 'defeat and failure: it tends to deny that high sense of expectation, that hope of ultimate triumph that sustains good combatants'. ${ }^{23}$ By integrating these themes into the series of biographical sketches that make up The American political tradition, and by focusing on figures with which readers would already be familiar, Hofstadter ultimately forged a version of popular history that maintained a critical stance towards the US past, and therefore invited a wider readership than any of his subsequent work.

\section{I}

In December 1945, Stanley Pargellis, the head of the Newberry Library in Chicago, took to the pages of the city's Sun newspaper to lament the state of contemporary historical writing:

${ }^{21}$ Eric Foner, Who owns history? Rethinking the past in a changing world (New York, NY, 2002), pp. $32-3$.

${ }^{22}$ Hofstadter, The American political tradition, p. xl.

${ }^{23}$ Hofstadter, The progressive historians, p. 466. 
For fifty years university specialists have been writing for one another, vaguely hoping that their books will be read outside the narrow family circle, but deriving their real satisfaction from the thought that if 20 men in the country know enough...to understand a weighty book on a subject, its author has done his duty and has justified the 10 years of work and study he put on it...The men who can write American history fit to match the achievements of the American people can be counted on one's two hands. ${ }^{24}$

Pargellis's anxiety about academics turning their backs on the reading public, writing for each other, and consequently doing an injustice to the subject matter of US history, was a widespread one. Arthur Schlesinger, Jr, for example, who was a peer of Hofstadter's in the generation of historians coming of age at mid-century, had written to his editor at Little, Brown \& Co. five years earlier that: "the two essentials of good history... are sound interpretation and writing colorful enough to reproduce a sense of the emotions and feelings of the period. Ordinarily you get one without the other.' ${ }^{25}$ Schlesinger, Jr, was writing to pitch the book that would become the Pulitzer Prize-winning The age of Jackson (1945), and was playing up to the prejudice that the majority of 'academic' historians were bad at writing, whilst the majority of 'popular' historians simply re-hashed national myths to no intellectual avail. In doing so, he implied that there was a niche in the market for histories that ably combined both popularity and complexity.

This was a strain of thinking that Hofstadter was keenly aware of as he wrote The American political tradition. In reviewing Schlesinger, Jr's, book for the New Republic, for example, he argued that a considerable proportion of 'widely praised and widely read' historical writing was actually 'second-rate or downright shoddy', and that it was therefore 'a pleasure to report on a book like this and find oneself part of a general chorus of approval'. ${ }^{26}$ Indeed, Hofstadter's desire to write for publications such as the New Republic was part of an active mission to develop a more popular style of writing. This is demonstrated in a letter he wrote to his friend Alfred Kazin soon after the review was published, in which he suggested: 'I am very much concerned to develop a popular medium. I am tired of academic writing and thinking. (Hence the essential lightness and even triviality of my current project.) ${ }^{27}$ The 'current project' was The American political tradition, which had been in gestation since early 1944, and it is particularly interesting that at such an early stage

\footnotetext{
${ }^{24}$ Stanley Pargellis, 'The lasting literature and public taste', Chicago Sun, 2 Dec. 1945, no page numbers, clipping in Arthur Schlesinger, Jr, Papers, Manuscripts, and Archives Division, New York Public Library (ASJP), box 527 .

${ }^{25}$ Schlesinger to Roger L. Scaife (15 Dec. 1940), ASJP, box 407 , folder 6.

${ }^{26}$ Richard Hofstadter, 'Democracy in the making', New Republic, 22 Oct. 1945, p. 541.

${ }^{27}$ Hofstadter to Kazin (n.d., c. Nov. 1945), Alfred Kazin Collection of Papers (AKC), Henry W. and Albert A. Berg Collection of English and American Literature, The New York Public Library.
} 
Hofstadter conceived of the book as an opportunity to widen the scope of his readership beyond the confines of the academy.

The main financial impetus for this effort came from a fellowship awarded to the historian by the New York publishing house Alfred A. Knopf, Inc., in 1945. The purpose of the award was to encourage exactly the type of projects in history, biography, and science that it was understood were absent from the US public sphere. As the advertisement for the award in 1945 made clear, 'it is the nature of the fellowships...made available as they are by a general publisher, that they can be awarded only to projects containing the promise of trustworthy scholarship combined with literary distinction of the kind that means some breadth of appeal'. ${ }^{28}$ In line with these expectations, Hofstadter's application to complete his work on the manuscript was described by an anonymous referee as 'the outstanding submission for our history fellowship'. ${ }^{29}$ However, Hofstadter was forced to split the $\$ 5$, ooo award with another scholar, primarily because their benefactors could not be convinced that the collection of biographical sketches for which Hofstadter had applied for funding would prove a bestseller. The award of the fellowship was the first indication of the potential of the manuscript, but the project's initial reception by its readers at Knopf also highlighted that he had much writing to do to make it a work of history that would resonate beyond the academy.

As Hofstadter's draft chapters arrived at the publishing house, excitement grew about the text's potential. However, the manuscript still did not have the coherence Hofstadter's editor, Harold Strauss, demanded. He therefore suggested that the historian write an introduction to tie the chapters together. In an internal memo, the editor explained his thinking: ' $H$. must ask himself "what in brief am I trying to say" - and then re-examine his own material in light of whether it advances or detracts from the central point he is trying to make.'3o It was this type of coherence, Strauss felt, which would aid the book's sales by providing a sense of narrative. ${ }^{31}$ Hofstadter agreed, and described the introduction as 'a kind of public relations exercise which will arouse interest and be of some use when promoting the book'. $3^{2}$ Even if the introduction to The American political tradition was 'only an afterthought', then, a few months before publication editor and author were in accord: it was vitally important, both as a means of reaching out to a readership beyond the Ivory Tower, and of highlighting the book's status as both a popular and a complex contribution to US historical writing. 33

Hofstadter's approach to his subject matter was particularly evident in The American political tradition's chapter on Abraham Lincoln. The historian

${ }^{28}$ Knopf fellowship advertisement (1945), AAKP, box $5^{64}$, folder 1.

29 'Report on Hofstadter application for Knopf fellowship', AAKP, box 1377, folder 6.

$3^{\circ}$ 'Report on Men and ideas in American politics' (6 June 1947), AAKP, box 3o, folder 12.

$3^{1}$ Strauss to Hofstadter (12 Dec. 1947), AAKP, box 30, folder 12.

${ }^{32}$ Hofstadter to Strauss (1 Dec. 1947), AAKP, box 3o, folder 12.

33 For Hofstadter's 'afterthought' comment, see The American political tradition, p. xxvii. 
suggested that the most accurate way to view the nation's sixteenth president, whose reputation had become especially shrouded in myth in the years since his assassination in $\mathbf{1} 86_{5}$, was through the lens of the widely held American ideology of 'self-help'. Hofstadter's chapter charted the Illinois politician's route to political power during the $1840 \mathrm{os}$ and $185^{\mathrm{os}}$, and argued that Lincoln's desire to 'make something of himself through his own honest efforts' demonstrated that he was driven by intense personal ambition, and was, therefore, 'typically American'.34 Even by the time he was presiding over the Union in the US Civil War, Lincoln was dedicated to using the power of the government to develop a 'system of social life that gave the common man a chance'. This meant that while he was 'politically on the radical or "popular" side of the fight', he was ultimately 'historically conservative' because he aimed to 'preserve a long-established order that had well served the common man in the past'.35 Lincoln's signature of the Emancipation Proclamation made this especially apparent. Its text, from Hofstadter's perspective in the late 1940s, had 'a wretched tone', because it emphasized freeing the slaves not because of their inherent humanity, but because it made political and military sense to do so. $3^{6}$ Rather than being a semi-mythical 'Great Emancipator', then, Lincoln stood as an ordinary, if very successful, politician.

In presenting these arguments, Hofstadter's chapter did not provide much by way of original scholarly observation. However, the historian weaved a narrative of Lincoln's career that, on the one hand, highlighted the 'high tragedy' of American politics, but, on the other, also demonstrated the inherently conservative nature of the president's approach to politics. ${ }^{37}$ For Hofstadter, Lincoln's tragedy was rooted in the fact that his relentless ambition to succeed went unfulfilled. Even in the aftermath of the Union's victory in the Civil War

he could see the truth of what he had long dimly known and perhaps hopefully suppressed - that for a man of sensitivity and compassion to exercise great powers in a time of crisis is a grim and agonizing thing. Instead of glory, he once said, he had found only 'ashes and blood'. $3^{8}$

This passage demonstrates Hofstadter's powerful prose style, as well as his eye for historical irony. The Lincoln presented in The American political tradition was a tragic figure who deserved his place in the pantheon of American political history, but whose actions could not go without criticism, and whose mythology required subtle discrediting.

Hofstadter worked hard to develop the lyrical prose style on display in The American political tradition's chapter on Lincoln. Writing to Alfred Kazin after

\footnotetext{
34 Ibid., pp. 127-8.

35 Ibid., pp. 160-1.

$3^{6}$ Ibid., p. 169 .

37 Ibid., p. 123 .

$3^{8}$ Ibid., p. 173 .
} 
the publication of The American political tradition, the historian reflected on his status as a writer:

One thing that's very important: don't class me with the genus historicus. I suppose you're right that they look down their noses at genus literarius, but I am really a suppressed litterateur who couldn't make the grade just writing good prose and had to go into history. Unlike my brethren I look up to writers, and I'm fearfully afraid of them, all of them, from competent journalists to literary critics. 39

As this quotation suggests, Hofstadter was searchingly aware of literary style. This is confirmed in several oral history interviews conducted with friends and colleagues soon after his untimely death in 1970. Elizabeth Earley, the wife of Frank Freidel, Hofstadter's colleague in his first job at the University of Maryland, suggested that at the time he was writing The American political tradition, the historian 'had... as big a thing about being a writer as about being a historian. He always looked at history as a writing skill.' $4^{\circ}$ Furthermore, Eric Foner, who was a graduate student of Hofstadter's in the 196os, suggested that Hofstadter 'was trying to reach out, not to the bestseller list, but to educated audiences in the hundreds of thousands if not millions. And he felt that...the form in which his works of history were presented was as important as their content'.$^{4^{1}}$ These recollections highlight Hofstadter's preoccupation with writerly style and his desire to engage with a 'general' readership. Read alongside the debates about the public function of historical writing into which The American political tradition intervened, the manner in which the book was commissioned by Knopf, and Hofstadter's attempt to complicate the historical reputation of a well-known figure such as Abraham Lincoln, they help to demonstrate the ways in which the book, in both its conception and execution, fruitfully mediated the competing prerogatives of popularity and complexity.

\section{I I}

Mid-century debates about the manner in which academics should reach out to audiences beyond the university were not confined to the historical profession. The literary critic Lionel Trilling, for example, was also serious about making complex ideas available to general readers. The liberal imagination (1950) exemplifies this aspect of Trilling's criticism: published two years after The American political tradition, it collected a series of essays that had originally appeared in niche periodicals during the $194 \mathrm{Os}$, all of which aimed to critique the relationship that developed between American literary criticism and Popular Front politics before and during the Second World War. Trilling described the job of the

\footnotetext{
39 Hofstadter to Kazin (n.d., c. $\left.195^{\circ}-3\right)$, AKC.

$4^{\mathrm{o}}$ 'Richard Hofstadter project: Elizabeth Earley' (Columbia Oral History Research Office, 1973, no. $146_{3}$ ), p. 9 .

$4^{1}$ 'Richard Hofstadter project: Eric Foner' (Columbia Oral History Research Office, 1973, no. 1306$)$, p. 16.
} 
critic as 'to recall liberalism to its first essential imagination of variousness and possibility, which implies the awareness of complexity and difficulty'. $4^{2}$ This message, he wrote to his editor in 1949, was intended for 'the general reader, not for the literature student alone', with the goal of 'addressing a crisis in our culture which requires bold and careful thought about our cultural beliefs'. 43 Trilling's goal was therefore aligned with Hofstadter's, albeit with different subject matter: he wanted to replace in the public mind what he saw as simplistic interpretations of American literature with those of more complexity and nuance. To this extent, he was very successful, with the book quickly selling over 100,000 copies. 44 However, Trilling ultimately succeeded in using The liberal imagination to announce himself as a public intellectual not only because of its impressive range and felicitous prose style, but also because of the way the book emerged into the literary marketplace as, in Thomas Bender's words, 'one of the first serious paperbacks', aimed at 'cultivated middle-class' audiences who 'enjoyed as well as respected intellect'.45 In making this case, Bender demonstrates the key role in the success of Trilling's book played by marketing, publicity, and the emergence of the paperback as an immensely popular phenomenon in the publishing world.

A similar context shaped the publication of The American political tradition. In the months leading up to the book's August 1948 release, attention at Knopf turned to its promotion, and how it could best be marketed as the kind of popular history that would appeal to a particular type of readership: what Hofstadter himself described as 'somewhere in between...the common American... and sober historians'.$^{6}$ The first major question centred on the manuscript's title. Hofstadter had originally proposed Men and ideas in American politics. However, Strauss felt that to have extensive saleability, the book needed to tap into what he perceived to be a public attitude of 'very considerable nostalgia' regarding the nation's history, and suggested that the title should indicate its status as a broad-ranging 'reinterpretation of the American past'. 47 This led him to propose Eminent Americans: and the growth of political traditions, which met resistance from the author:

I have a very serious objection to the subtitle and the growth of political traditions. My book does not demonstrate any particular growth - indeed, if anything it suggests a relative absence of real growth in American political tradition. Changes,

$4^{2}$ Lionel Trilling, The liberal imagination (New York, NY, 1950), p. xxi.

43 Trilling to Pascal Covici (8 Aug. 1949), Lionel Trilling papers, Columbia University Manuscripts and Rare Books Library, box 6 , folder 2.

44 Thomas Bender, 'Lionel Trilling and American culture", American Quarterly, 2 (1990), pp. $324-47$, at p. 324 .

45 Ibid., p. 324-5.

$4^{6}$ Hofstadter to Howard K. Beale ( 11 Feb. 1948), Richard Hofstadter papers (RHP), Columbia University Manuscripts and Rare Books Library, Uncatalogued Correspondence, box 1 .

47 Strauss to Hofstadter (1 2 Dec. 1947), AAKP, box 3o, folder 12. 
permutations, combinations, yes - but almost no growth to speak of. Shrinkage would be more to the point. $4^{8}$

The response of the publishing house to Hofstadter's objections is represented in an outline table of contents prepared several months later, which gave the book the title Eminent Americans and the shape of political traditions: great men and great ideas in the American past. 49 Nonetheless, the author remained displeased by his editor's attempt to aggrandize the book's contents, objecting to the repeated use of the word 'great', which he described as 'a violation of the spirit of the book'. $5^{\circ}$ In making these points, Hofstadter repeatedly demonstrated that he had no interest in compromising the complexity of his historical message by having his book publicized as a contribution to American national mythology.

The American political tradition's final title was reached by Strauss and Hofstadter over lunch in late March 1948, several months after the debate had started..$^{1}$ If, from a publicity standpoint, it is possible to understand the editor's attempts to use the title to magnify the book's status, it is also easy to sympathize with the author's reluctance to allow commercial interests to overstate the claims being made for his scholarship. However, what these dogged attempts by Strauss to get Hofstadter to reconsider the book's title also highlight is how its precise position within the literary marketplace would impact its status as popular history. Whilst the historian seemed to be more concerned with the ideas contained within the pages of the manuscript, his editor recognized that its title would structure the meaning and importance of the text in the minds of its readers. Furthermore, he was concerned with the responses of literary tastemakers at newspapers and periodicals, who would decide whether the book would be reviewed.

After The American political tradition was published, Hofstadter demonstrated that he was well attuned to this important literary process. The book received some positive early reviews, and the author was keen to make sure that they were used as publicity. Going over his editor's head by writing to Alfred A. Knopf himself, Hofstadter criticized the publicity strategy followed by the house:

What concerns me is that nothing has been done in the way of advertising to acquaint the potential audience of the book with the composite estimate of its critics...You do not hit the front page of the Times every other week, especially with a non-fiction item, nor do you often get quite such reviews from responsible critics. $5^{2}$

\footnotetext{
$4^{8}$ For the title suggestions, see Strauss to Hofstadter (23 Dec. 1947), AAKP, box 3o, folder 12. For the response, see Hofstadter to Strauss (3o Dec. 1947), AAKP, box 3o, folder 12.

49 'Outline table of contents for Eminent Americans' (23 Jan. 1948), AAKP, box 3o, folder 12.

$5^{\circ}$ Hofstadter to Strauss (25 Mar. 1948), AAKP, box 3 o, folder 12.

$5^{1}$ Brown, Richard Hofstadter, p. $5^{2}$.

$5^{2}$ Hofstadter to Knopf (16 Oct. 1948), AAKP, box 3o, folder 12.
} 
Hofstadter's negative analysis of the publisher's publicity strategy once again demonstrates his desire to reach an audience beyond the historical profession. In another letter to Knopf, the historian made this point even more explicitly, by citing the example of a review in the Cleveland News, which he thought might be of 'special value' because it described the book as 'clearly and simply for the enjoyment of the general reader'.53 Hofstadter therefore estimated that his corner of the literary market was located firmly in the space between a specialized academic audience and a mass readership.

In line with this estimation, The American political tradition was selected as a dividend by the History Book Club (HBC).54 Established in 1947 by the popular historian and journalist Bernard DeVoto, the HBC brought a group of prominent historians together to select books for its members that would prove entertaining, but that would also link the past directly to the present. Arthur Schlesinger, Jr, was one of the professional scholars brought on board by DeVoto, and, as Erik Christiansen has shown, the pair shared the belief "that history served little purpose if confined to the all but enclosed community of professional historians'.55 The HBC therefore tapped into, and attempted to address, the widespread anxiety amongst intellectuals of the period about the function of American historical writing and its accessibility to a wide range of audiences. Again, though, the $\mathrm{HBC}$ was not interested in publicizing history that was merely popular: all of the key figures involved shared a commitment to liberal politics, and were only interested in the type of books that would confront 'growing corporate power and the resurgence of conservatism' in post-war America. $5^{6}$

As Janice Radway has shown, sales networks of this type worked to delineate the parameters of popular taste, defining the 'general reader' as a 'rejection and critique of some other reader, presumably a reader not general but focused, professional, technical and specialized'.57 The American political tradition's place within this literary nexus was cemented when, in 1954, it was one of the first books issued as a part of Knopf's non-fiction paperback imprint, Vintage Books. From the late 193os onwards, what has come to be termed the 'paperback revolution' transformed American book publishing. Paperbacks were cheaper to print and distribute than cloth-bound books, and sold in significantly larger numbers. They were more attractive to readers, who found pocket-sized books easier to transport. Indeed, as mass distribution became the norm, readers also found books easier to purchase, as paperbacks became available not only in specialized booksellers or via mail order, but also in drug stores, train stations, and bus terminals. $5^{8}$ Paperback sales and

53 Hofstadter to Knopf (19 Oct. 1948), AAKP, box 3o, folder 12.

54 William A. Koshland to Hofstadter (1 8 May 1949), AAKP, box 49, folder 9 .

55 Christiansen, Channeling the past, p. 25.

$5^{6}$ Ibid., p. 24 .

57 Janice Radway, A feeling for books: the book-of-the-month club, literary taste, and middle-class desire (Chapel Hill, NC, 1997), p. 10.

$5^{8}$ Kenneth C. Davis, Two-bit culture: the paperbacking of America (Boston, MA, 1984), p. xii. 
profitability therefore expanded dramatically in the post-war period: in 1947, approximately 95 million paperbacks sold for $\$ 14$ million, but by 1959 , these figures had risen to 286 million and $\$ 67$ million respectively. 59

Vintage Books did not aim at the type of mass readership these sales figures imply, though, and instead defined itself as a literary institution dedicated to mediating between popularity and complexity. As Jason Epstein, the founder of Anchor Books, an outgrowth of Doubleday and a direct competitor to Vintage, suggested in 1974, "when Anchor Books and Vintage began they tried to occupy some ground which was free at the time; that is, they...were trying to reach a much smaller and more specific audience, mainly academic, literary - specialized in these and other ways'. ${ }^{60}$ As a consequence, the books published by Anchor and Vintage became known as 'egghead paperbacks' ${ }^{61}$ An instructive 1954 article in Newsweek noted the prominence of this literary phenomenon, arguing that the books' popularity derived from 'the lightening spread of popular education, and with it the striking rise in public tastes. Drugstore book racks, once the undisputed home of Mickey Spillane, now also shelter the paper-bound works of Plato, Shakespeare, Freud, and St. Augustine.' ${ }^{62}$ Within this context, The American political tradition was an ideal candidate for a Vintage edition, and its publication as a paperback dramatically increased its sales. ${ }^{63}$ In 1969, Hofstadter was able to write to his then editor at Knopf, Ashbell Green, that, 'after fifteen years of paperback publication, The American political tradition is within striking range of its 1,000, ooo $^{\text {th }}$ copy'. ${ }^{6}$ Two years after the historian's death, Green wrote to his widow, Beatrice Hofstadter, to report the annual sales figures for all of his books published by Knopf. The American political tradition had outstripped his other titles by a significant magnitude, selling 49,259 copies in 1971 and 46,116 in $1972 .{ }^{6}$ The public impact of Hofstadter's book, along with its status as popular history, is therefore unimaginable without the opportunities provided by the paperback revolution, and the position of Vintage Books within it.

59 Beth Luey, 'Modernity and print: the United States, 189o-1970', in Simon Eliot and Jonathan Roes, eds., A companion to the history of the book (Oxford, 2009), p. 376.

6o Jason Epstein, 'Views on publishing', Publisher's Weekly, 16 Dec. 1974, p. 5, cited in Davis, Two-bit culture, pp. 209-10.

61 Hans Schmoller, 'The paperback revolution', in Asa Briggs, ed., Essays in the history of publishing: in celebration of the 25 oth anniversary of the house of Longman, I724-1974 (London, 1974), p. 305 .

62 'Eggheads: cracking the enigma', Newsweek, 8 Oct. 1956, p. 57, cited in Aaron S. Lecklider, 'Inventing the egghead: the paradoxes of brainpower in Cold War American culture', Journal of American Studies, 45 (2011), p. $25^{\circ}$.

${ }_{3}$ Harry N. Scheiber, 'A keen sense of history and the need to act: reflections on Richard Hofstadter and The American political tradition', Reviews in American History, 2 (1974), pp. 445$5^{2}$, at p. $44^{6}$.

${ }_{4}$ Hofstadter to Green (2o Oct. 1969), AAKP, box 833, folder 8.

65 Green to Beatrice Hofstadter (21 Dec. 1972), AAKP, box 833, folder 8. 
In his 1960 essay 'Masscult and midcult', which was originally published in the organ of the New York Intellectuals, Partisan Review, Dwight MacDonald criticized what he viewed as the increasing commoditization of American culture in the post-war period. In his view, publishers had adopted 'a new subjective approach in which the question is not how good the work is but how popular it will be'. Accordingly, he argued, books were treated as commodities and judged purely on 'audience-response'. ${ }^{66}$ MacDonald believed this process of commoditization (present in music, film, and art as well as literature) had created not only a form of 'masscult' that actively parodied high culture, but also a more pernicious form of 'midcult', that sought to make difficult ideas and concepts saleable to as wide an audience as possible. Ultimately, for MacDonald, this created the 'agreeable ooze of the Midcult swamp', in which readers were never challenged by popular authors. ${ }^{67}$

Hofstadter credited his middlebrow readership with considerably more intelligence than did MacDonald, and therefore developed and sustained an alternative version of scholarly engagement with a large public audience. The American political tradition was a constituent part of the cultural process identified in 'Masscult and midcult', and the book was actively promoted as a work of popular history, was offered as a dividend by the HBC, and continued to sell tens of thousands of paperback copies years after its publication date. However, in popularizing his scholarship, Hofstadter did not pander to nationalistic sentiment about America's past. Instead, he insisted that the critical tone of his writing be emphasized in Knopf's publicity for the book, a fact which, it seems safe to assume, influenced its adoption by the HBC, an institution that had no interest in pandering to national nostalgia. Hofstadter also insisted that the middlebrow audiences at which he aimed his work be taken seriously. They were intelligent, responsible, and ready for a nuanced approach to the American past. As a consequence, the approach to popular historical writing exemplified by The American political tradition undercuts an understanding of middlebrow non-fiction as being unable to articulate complex and critical analyses of US society, and demonstrates that the book's place within the midcentury literary marketplace played a significant role in shaping the version of national history Hofstadter articulated.

\section{V}

Of course, Hofstadter and his publishers were not the only contributors to the process by which the meaning of The American political tradition was structured within the mid-century popular historical imagination. The scholars, intellectuals, and journalists who reviewed the book upon its publication in August

66 Dwight MacDonald, 'Masscult and midcult', in idem, Against the American grain (New York, NY, 1962), pp. 18-19.

67 Ibid., p. 74 . 
$194^{8}$ also played a significant role, and The American political tradition received attention in a wide range of media, from scholarly journals in history and political science, to a front-page treatment in the New York Times Book Review and numerous reviews in local newspapers across the US. During late 1948 and throughout 1949, three themes emerged out of the critical readings the book received: its status as a popular history; its critical, complex treatment of the national past; and its relevance to contemporary political discourse, in particular the $194^{8}$ presidential election and the continuing significance of the politics of the Depression era in mid-century America.

Several reviewers were impressed by the manner in which The American political tradition fused credible scholarship with writerly panache. 'Hofstadter's style is bright and sharp', suggested The American Political Science Review, comparing the author's prose to 'an axe laid to the underbrush of legend; smooth and clever, as a fresh breeze ventilating the stodgy atmosphere of academic research' ${ }^{68}$ Arthur Kooker in the Pacific Historical Review shared this conclusion, albeit in more restrained terms, and suggested that the book was 'scholarly, yet written with much charm and wit'.69 The New York Times Book Review, furthermore, 'heartily recommended' it as required reading in a presidential election year. $7^{\circ}$ Hofstadter's fusion of erudition with readability also led reviewers to concur with Merle Curti's private observation that the book was a prime example of popular historical writing. In Commentary, Oscar Handlin described the book as 'popular history at its best'. $7^{1}$ The American Quarterly's reviewer, Daniel Aaron, concurred: 'The American political tradition is a good example of popular writing in the best sense - learned and readable, dispassionate and critical.' 72 These repeated invocations of Hofstadter's work as the 'best' form of popular history implied that his book was better than a range of other, albeit unnamed, popular historical works. Indeed, this was a sentiment that had been foreshadowed in a letter written by the journalist Matthew Josephson to Hofstadter after reading an early draft in May 1948: 'It is literally years since I've read anything this "grownup" on the subject of our political traditions... Everywhere I see only James Truslow Adamses all around me.'73 Adams was a popular historian best known for popularizing the concept of the 'American Dream' in his 1931 book The epic of America, and, in making this comparison, Josephson suggested that Hofstadter had actively avoided joining the ranks of

\footnotetext{
68 Albert G. Huegli, 'The American political tradition by Richard Hofstadter', American Political Science Review, $4^{2}$ (1948), pp. $1214^{-1} 5$.

69 Arthur R. Kooker, 'The American political tradition by Richard Hofstadter', Pacific Historical Review, 18 (1949), p. 254 .

$7^{\circ}$ Gerald W. Johnson, 'Some tenants of the White House: shrewd appraisals of our presidents, and aspirants to that trying office', New York Times Book Review, 19 Sept. 1948, p. 1.

$7^{1}$ Oscar Handlin, 'America’s political tradition', Commentary (July 1949), p. 98.

$7^{2}$ Daniel Aaron, 'The American political tradition by Richard Hofstadter', American Quarterly, 1 (1949), p. 96.

73 Matthew Josephson to Richard Hofstadter (18 May 1948), RHP, box 20.
} 
those writers who disavowed complexity in order to please readers' tastes for historical writing that heaped praise on the American way of life.

Reviewers for the literary periodicals the Yale Review and the Antioch Review also grappled with the intellectual and political implications of the book's position within the genre of popular history. For example, Fred V. Cahill suggested that:

Whether one believes in celebrating the past or seeks to disprove an accepted belief in its relevance, it is clearly a function of scholarship to make the traditions of a society available to those ultimately responsible for its welfare. In a society based upon popular choice, as we like to suppose ours to be, this imposes certain obligations upon historical writing and has resulted in the increasingly recurrent phenomenon of the 'popular history'. Mr. Hofstadter's book is an excellent example. It deserves and will undoubtedly achieve a wide audience. 74

Cahill thereby set the genre of popular history within the contexts of both American democracy and the politics of capitalist consumption: if the nation's politicians were to be held to account by its citizenry, historians would have a significant role to play by offering their readers, who were also consumers, the opportunity to purchase their work and therefore engage with the nation's political traditions. An early academic proponent of the discipline of American Studies, Louis Filler, made a similar connection. He compared Hofstadter's work to Schlesinger, Jr's, The age of Jackson, which, he suggested, had benefited from literary institutions such as the Book Find Club, and had therefore received 'a striking amount of popular appreciation'. The critic went on to suggest that the prime source of the reputation of Schlesinger's book was the manner in which he had 'read a kind of Franklin D. Roosevelt into Andrew Jackson, and in so doing warmed the cockles of many a liberal heart'.75 Filler clearly preferred Hofstadter's more cynical portrait of the seventh president as 'a representative of "liberal capitalist" tendencies, rather than a thinker or humanitarian'. ${ }^{6}$ In making this point, he argued that a debunking spirit was vital to the manner in which Hofstadter's book used the popular historical form to make a political intervention. This was also the case with his portrait of Abraham Lincoln:

Apparently he feels that too intense a concern with the 'great' Lincoln, as opposed to the Lincoln whom his contemporaries knew, would result in losing the real Lincoln - a Lincoln who could be recognized by reasonable people and studied for light on our own times as well as his. 77

74 Fred V. Cahill, 'Twelve Americans', Yale Review (Spring 1949), pp. $5^{6} 5^{-6}$, at p. $5^{6} 5^{\text {. }}$

75 Louis Filler, 'Tenets of scientific skepticism', Antioch Review (Spring 1949), pp. 88-98, at p. 90 .

$7^{6}$ Ibid., p. $9^{1 .}$

77 Ibid., p. $9^{2}$. 
In making this point, Filler, in a similar manner to Cahill, sought to draw his readers' attention to the public significance of popular history: The American political tradition would help them to understand their nation's past, and therefore to make informed decisions about contemporary political issues.

This treatment also demonstrates that contemporaneous reviews of The American political tradition were sensitive to the critical tone of its account of national history. In the Mississippi Valley Historical Review, for example, C. Vann Woodward suggested that in certain hands, arguments for unity of purpose amongst American politicians could have contributed to 'the literature of nationalism and complacency'. ${ }^{8}$ However, Hofstadter's book was 'severe, analytical, and unsparing', a tone with which Woodward was quite comfortable.79 Reviewers in less scholarly forums agreed. The conservative New York Herald Tribune, for example, suggested that rather than providing readers with 'an easy chair at the national pageant', Hofstadter took them 'firmly by the hand...down the long trail to active investigation'. ${ }^{80}$ Similarly, but from a vastly divergent position on the political spectrum, the Communist Party USA's newspaper, the Daily Worker, drew a comparison between Hofstadter's analysis and its Stalinist worldview:

Neither a naïve believer in, nor a cynical peddler of, the hokum which passes conventionally as American history, the author of The American political tradition has kept his eye - and his pen - on the basic social and economic issues which agitated the U.S. on the road to its present status as the world's great capitalist power. ${ }^{81}$

In each of these reviews, it is clear that Hofstadter's historical arguments were understood by mid-century readers to have avoided celebrations of the American political tradition, and to have offered a rendering of the nation's past in complex yet readable terms.

This becomes even clearer upon consideration of the relationship between The American political tradition and its immediate party-political context. The politics of the Depression era and their significance in the immediate post-war period loom large in The American political tradition's exegesis of American historical development. The final two chapters of the book cover Herbert Hoover and Franklin Roosevelt, and discuss their competing social and political visions in relation to the individualist tradition Hofstadter argued was so central to American political life. In this analysis, 'the things Hoover believed in efficiency, enterprise, opportunity, individualism, substantial laissez faire, personal success, material welfare - were all in the dominant American tradition'.

$7^{8}$ C. Vann Woodward, 'The American Political Tradition by Richard Hofstadter', Mississippi Valley Historical Review, 35 (1949), pp. 681-2, at p. 681.

79 Ibid., p. 682.

8o John K. Hutchens, 'Books and things', New York Herald Tribune, 16 Sept. 1948, no page number, clipping in AAKP, box 1377 , folder 2.

${ }^{81}$ Robert Friedman, 'American political tradition: essays on the men who made it', Daily Worker (n.d.), no page number, clipping in AAKP, box 1377, folder 2. 
However, whilst 'in the language of Jefferson and Lincoln, these ideas had been both fresh and invigorating; in the language of Hoover they seemed stale and oppressive'.$^{82}$ Hoover's failure in the face of the economic crisis brought on by the crash of 1929 therefore signalled the bankruptcy of the American political tradition Hofstadter had so carefully and iconoclastically traced: it was unable to win popular support because 'the people had no ear for spokesmen of the old faith'. ${ }^{8} 3$ Roosevelt was spared such a withering treatment, but Hofstadter was nonetheless keen to highlight the contradictions of his presidential administrations. He was, at heart, a patrician, who had been reared on 'a social and economic philosophy rather similar to Hoover's' ${ }^{84}$ By implementing the policies of the New Deal, he demonstrated that he was able to transcend the temperament of his upper-class background in order to become 'an individual sounding-board for the grievances and remedies of the nation', which he tried to weave into a programme that would correct the problems caused by an unwavering faith in laissez-faire capitalism. ${ }^{85}$ However, in Hofstadter's analysis, Roosevelt's policies were by no means coherent, and he wavered between prioritizing the interests of big business and implementing an approach that would emphasize channelling the fruits of future prosperity into a programme of 'distributive justice'. ${ }^{86}$ As such, if Hoover functioned as the villain of Hofstadter's narrative, Roosevelt was by no means its hero:

There are ample texts in his writings for men of good will to feed upon; but it would be fatal to rest content with his belief in personal benevolence, personal arrangements, the sufficiency of good intentions and month-to-month improvisation, without trying to achieve a more inclusive and systematic conception of what is happening in the world. ${ }^{87}$

Hofstadter's suggestion that the Depression led the American electorate to become tired of Hoover's stale rhetoric, and his argument that Roosevelt's view of American capitalism, whilst in some dimensions progressive, was not 'systematic' enough, both demonstrate the influence of the ideas of post-war liberalism in his work. This was recognized and amplified by reviewers and critics of the book. Writing in the Nation, Perry Miller suggested that The American political tradition was 'an index of its times', in that it found contemporary American liberalism 'rudderless and demoralized', and was therefore an implicit rejection of the Democratic Party and its presidential candidate Harry S. Truman. ${ }^{88}$ This sense of political relevance was not restricted to reviews written in the buildup to the $194^{8}$ election. Soon after Truman's inauguration, the William and

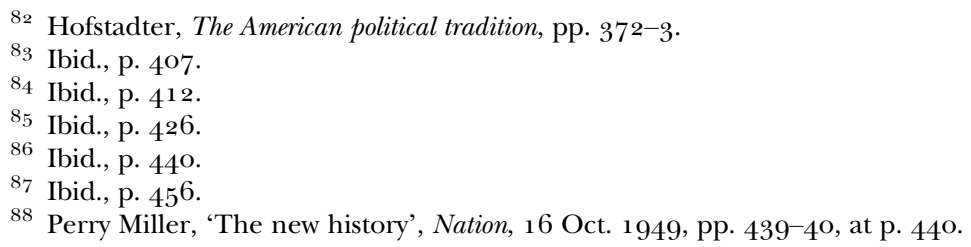


Mary Quarterly's reviewer, Arthur Mann, suggested that the book 'decries the "national nostalgia" and urges that we adopt a new ideology of centralized planning for modern corporate America. ${ }^{89}$

As Aaron Lecklider has argued, the position of the 'egghead' intellectual within American mid-century culture was a paradoxical one. Eggheads were celebrated for their intellectual superiority, but at the same time deemed 'repellent' and 'transgressive' because of the ways their arguments and identities chipped away at established political, racial, and gender norms. $9^{\circ}$ In light of this observation, what is most revealing about the reception of The American political tradition is that it was celebrated precisely because of its transgression of national historical pieties. The book was understood as a critical intervention into public discourse from the left of the political spectrum, and by no means a celebration of American values. The numerous positive reviews it received therefore highlight how the book functioned in its late 1940s context as a critique of individualism, charting its intellectual lineage in the political thinking of influential historical figures, as well as the downturn of its popular fortunes during the 1930 . In this sense, then, it used historiography as a form of political critique, and did so very effectively. The response to The American political tradition's version of popular history in academic journals and literary periodicals, as well as the national and local press, also highlights the continuing relevance of questions concerning political economy and the limitations of contemporary capitalism within mid-century popular American historical writing. Hofstadter's writing style may have appeared to his readers as clear, provocative, and inherently 'popular', then, but he was also centrally concerned with the development of American liberalism in the aftermath of the Second World War, and keen to press for a more radical view of politics than that provided by the contemporary Democratic Party.

V

In order to understand the full significance of Richard Hofstadter's The American political tradition, it is necessary to build on extant debates about the book's connections to the 'consensus' school of US historiography, and acknowledge the important relationships that developed between its author's popular historical writing and the literary and political contexts in which it emerged. The book responded to post-war anxieties about the relevance of national history to contemporary politics and culture, as well as to a concern with making specialized knowledge in all fields accessible to non-academic audiences. Hofstadter was keenly aware of these debates, as were his editors and publicity team at Knopf and the book's reviewers in the national and local press.

\footnotetext{
89 Arthur Mann, 'The American political tradition by Richard Hofstadter', William and Mary Quarterly, 6 (1949), p. 302.

$9^{\circ}$ Lecklider, 'Inventing the egghead', pp. $24^{8-52 .}$
} 
The startling popularity of The American political tradition therefore presents an opportunity to rethink the manner in which national history was conceived in the mid-century US public sphere. Whilst the abstract notion of 'popularity' was vitally important to Hofstadter and his peers, an attendant respect for 'complexity' was also deemed vital. These values were important in demonstrating the relevance of an increasingly professionalized academic discipline, in complicating contemporary perceptions of so-called 'middlebrow' culture, and in providing popular historical writing with a deliberately liberal accent as it intervened in the political debates of the late 1940 os.

These are contexts that seem particularly relevant today, in an age when the decline of 'public intellectuals' who are able to write boldly and engagingly for a general readership is regularly decried on both sides of the Atlantic, and those writing blockbusting popular histories are much less likely to be directly associated with the historical profession. $9^{1}$ Whilst historians in the early twentyfirst century work in an altogether different environment, then, Hofstadter's example might provide some clarity about the possibilities of producing engaging writing aimed at an audience outside of the academy, at the same time as it serves as a reminder of the responsibility of historians to function not as chroniclers of national pieties, but as negotiators of paradox, irony, contingency, and criticism, no matter what the subject matter.

$9^{1}$ The classic denouncement of the decline of public intellectual discourse is Russell Jacoby, The last intellectuals: American culture in the age of academe (New York, NY, 1987). A more recent discussion, along with a wealth of quantitative data, is Richard A. Posner, Public intellectuals: $a$ study of decline (Cambridge, MA, 2003). For an example of how these arguments have been directed towards the historical profession, and in specific relation to the popular historian David McCullough, see Sean Wilentz, 'America made easy: McCullough, Adams, and the decline of popular history', New Republic, 225 (2 July 2001), pp. 35-40. 